\title{
A Study on English Teaching Strategies in Higher Vocational Colleges under the Background of Educational Internationalization
}

\author{
Hongxia Zhao \\ Dalian Vocational and Technical College \\ 116035, Dalian, China \\ GQ_Latte@163.com
}

\begin{abstract}
With the development and deepening of economic globalization, the internationalization of higher vocational education has become an inevitable trend of social development. Under the background of the globalization of higher vocational education, higher vocational colleges have obtained important opportunities for development. Taking English education as the breakthrough point, higher vocational colleges should seize these opportunities to form a correct international vision, grasp the reform trend of English education and foster the students' capacity of applying English to their posts effectively, thus greatly facilitate the implementation of English teaching activities, improve the effectiveness of teaching and promote the development of individualized teaching.
\end{abstract}

Keywords-Higher vocational education; Internationalization; Business English; Teaching strategies

\section{INTRODUCTION}

In the course of nearly 40 years of reform and opening up, higher vocational education in China has been greatly developed, forming a multilevel vocational education pattern. "China has established the world's largest vocational education system. There are more than 13,300 higher vocational colleges, nearly 30 million students, and nearly 10 million graduates each year. We have trained more than 200 million employees in various fields." [1] The vigorous development of vocational education for nearly 40 years has provided tremendous labor support and technical support for China's modernization.

At present, China has become the world's largest importer of education and education trade market. China's higher vocational education is the earliest open field of education service trade and has become the world's educational service. The internationalization of higher vocational education has become an inevitable trend in the development of vocational education.

The "Belt and Road" strategy of China has strengthened the communication and cooperation between China and the countries and regions along the route. As a bridge of communication, the language is the key to all kinds of communication between the countries along the route. Under the background of "Belt and Road", higher vocational colleges have obtained important opportunities for development. In order to seize these opportunities, higher vocational colleges must take language education as the breakthrough point. In order to meet the language requirements of "Belt and Road" construction, the higher vocational colleges should offer relevant language courses or majors [2].

As an international language, English is also the main working language in most countries along the route. Therefore, taking English education as an example, this paper explores the ways to effectively cultivate students' English application ability related to their posts through the reconstruction of curriculum system and the reform of teaching methods. It is of great significance to meet the needs of socialist modernization and "Belt and Road" construction.

\section{ENGLISH TEACHING IN HIGHER VOCATIONAL COLLEGES SHOULD HAVE A CORRECT INTERNATIONAL VIEW}

\section{A. Strengthening the Internationalization of Educational Concept}

What is emphasized here is not only the higher vocational education leaders but also the lower level units and the participants in education should develop the internationalization consciousness. We should improve the major foreign affairs mechanism as soon as possible so that the concept of education departments, colleges, and educational participants will be changed. Recently, the concept of internationalization has prevailed among the upper level of the government and schools, while the lower level of schools and government have not gained same cognition. The college, teachers and students should integrate the concept of internationalization into its discipline development, talent training and even learning rather than passively be involved in the construction of the internationalization of the school, making internationalization no longer a requirement, but a need. 


\section{B. Establishing the Teaching Content and Curriculum System in line with the International Standards}

After the formation of the concept and operation mechanism of internationalization, it is necessary to enter the concrete process of higher vocational education activities to achieve the effect. Curriculum and teaching are the most concrete and complex links in the process of educational activities. At present, the international dimension, scientific and reasonable curriculum system and teaching content is a condition for its national and international accreditation, which serves as an important part of the internationalization process of higher vocational education.

The internationalization of curriculum is reflected in the internationalization of teaching materials, which requires the introduction of foreign textbooks, especially the original textbooks. Besides, the introduction of international cuttingedge issues and scientific and technological achievements into the classroom is also an essential ingredient. It is especially worth mentioning here that the double-degree course and the cooperative mode of running a school are more effective ways to construct the international curriculum.

Secondly, it is necessary to strengthen the construction of international courses and to increase the number of courses related to cross culture, foreign affairs or international affairs. It is necessary to introduce the current basic knowledge of international politics, world and national economy, culture, history, geography into teaching material and classroom, fostering students' international vision and enhance their international consciousness.

The third is to increase the proportion of foreign language courses because foreign language competence is a necessary condition to achieve the internationalization of higher vocational education and one of the important indicators to measure the internationalization of higher vocational education, and also one of the problems we need to solve at this stage. In order to improve the foreign language proficiency of teachers and students in schools, it is necessary to focus on training a number of young teachers who can teach in all foreign languages, especially by increasing the proportion of courses taught by foreign teachers so as to create a relatively pure environment for foreign language teaching and communication. It is necessary to improve students' foreign language listening and speaking ability and crosscultural communication ability, changing the situation that the foreign language of school teachers and students is always a short slab of international development.

\section{Actively Promoting the International Flow of Educators}

The teacher is the decisive factor to improve the quality of education and is the concrete implementer of the teaching idea Therefore, the internationalization of teachers is the premise and foundation of the internationalization of higher vocational education. The internationalization of teachers determines the success or failure of internationalization of higher vocational education. We should consciously and systematically train a group of academic backbone with great academic potential, high foreign language proficiency and strong ability in international activities, supporting them to study abroad, participate in international conferences and carry out cooperative research.

In addition, the introduction of overseas high-end talents is still the most direct and effective way to help the development of international disciplines. In the process of internationalization of higher vocational education in China, we should fully mobilize government resources and higher vocational colleges and other departments to consummate the security mechanism in the discovery, introduction and management of overseas talents. It is essential to increase the introduction of overseas talents and academic teams, especially to strengthen the introduction of overseas young scholars with potential, which can not only reduce the introduction costs, but also greatly enhance the teachers of higher vocational colleges in China.

\section{REFORM TREND OF FOREIGN LANGUAGE EDUCATION IN HIGHER VOCATIONAL COLLEGES}

\section{A. Reforming the Traditional English Curriculum System}

In view of the bottleneck of the development of English education in higher vocational colleges, higher vocational colleges should renew their educational concepts, grasp the pulse of the times, and construct an English curriculum system with higher vocational characteristics and meet the needs of internalization of vocational education and the market.

The vocational characteristics of higher vocational education also make the vocational English education itself unable to separate itself from its professional characteristics and the purpose of English education in higher vocational colleges. It is necessary to cultivate students' English application ability in a certain profession, which is in line with the goal of talents training in higher vocational and technical education in our country. Although the goals of higher vocational training have been changing for many years. From the "technical talents" to the "practical talents" put forward at the beginning, and then to the "highly skilled talents" put forward now, the characteristics of practicality, application and skills are emphasized.

There is a widespread consensus that while strengthening the training of English language foundation and basic skills, we should pay attention to the cultivation of students' practical communicative competence in using English. This idea indicates that English education in higher vocational colleges shoulders the task of cultivating students' English basic knowledge and skills as well as their communicative competence linked to their future work.

Based on the more mature theory and practice of the educational and academic circles, the goal of English education in higher vocational colleges embodies the process from EGP to ESP and EOP. Therefore, in keeping with the goal of English teaching in higher vocational education, we should design an English course system in accordance with the rules of English teaching in higher vocational colleges, which is helpful to gradually cultivate students' basic knowledge and basic skills of English as well as their applied and professional abilities [3]. 


\section{B. Promoting the Application of Modern Teaching Methods of English Teaching}

"Development Plan for the Education Informatization 2011-2020" and "Opinions of the Ministry of Education on Speeding up the Development of Informatization in Vocational Education" clearly pointed out that the work of promoting the modernization of vocational education with information technology has been raised to a new height. In the information age, the English classroom is no longer a simple "student + textbook + teacher" interaction while the innovation drive will become the main theme of the English classroom. Different from other subjects, English teaching pays more attention to language interaction and situation creation, so information technology has more space and more expressive power in English teaching.

Under the strategic plan of "Belt and Road" of our country, the status of English teaching in higher vocational colleges has been promoted. Actively using various modern means to assist English teaching can facilitate the development of English teaching and improve the teaching effect. The main ways of information-assisted English teaching are as follows:

The first is the use of traditional English teaching platform, which can realize the basic functions of listening, speaking, reading, writing, translation teaching, English proficiency testing and facilitate English teaching practice.

The second is the application of traditional multimedia technology, namely the use of audio, video, power point and other ways that assist English teaching.

The third is the construction of online English teaching platform, namely WeChat, BBC apps and so on, which can greatly promotes students' autonomous and individualized learning of English courses and at the same time broadens the time and space of English teaching.

The fourth is the construction of English teaching resource bank. MOOC and Micro-class gradually become the present mode of English online courses, which are open to share with high-quality English teaching resources.

The fifth is the use of new teaching methods in English teaching, such as flip classroom, Moso Teach, etc. Informatization is the direction of English teaching reform. Therefore, as for the English teaching in higher vocational colleges, we should make use of all kinds of information means and multimedia technology with the help of all kinds of positive factors brought by the good information ecological environment.

The new network teaching methods, such as MOOC class, Micro class, flipping class, etc., especially through the realization of mobile technology, realize the interaction between online and offline learning, synchronous and asynchronous learning, etc. Teacher-student interaction, students' interaction and human-computer interaction successfully broaden the teaching space and time, promoting the development of individualized teaching [4].

\section{Strengthening the Study of the Evaluation of Foreign Language Proficiency of Higher Vocational College Students}

Under the background of the globalization of vocational education, the foreign language level of the students in higher vocational colleges has become the bottleneck of the internationalization of higher vocational education. Whether engineering students or students of business English major, their foreign language proficiency is very difficult to achieve IELTS 5.5. Therefore only vigorously strengthens higher vocational student foreign language training can the talent become a necessary factor to promote the internationalization of higher vocational education. Based on the top-level design of the "National Foreign language proficiency Assessment System", the current foreign language teaching in higher vocational colleges should carry out study of China English Proficiency Scale and study the corresponding criteria for vocational colleges. It is urgent to explore the vocational colleges foreign language evaluation system to adapt to the new form of foreign language teaching, the implementation of higher vocational foreign language curriculum teaching and improvement of student academic evaluation system [5].

\section{1) Changing the concept of evaluation}

The foreign language teaching of higher vocational colleges should follow the construction of Chinese Foreign Language Proficiency Evaluation System, adhering to the principles of development, pluralism and dynamics in the evaluation of students' foreign language competence. We should not only assess the students' mastery of foreign language knowledge, communication skills, but also pay attention to the cultivation of students' emotion, attitude and values. Resulting from the cycle of "examination-oriented teaching and learning", the traditional foreign language teaching will embrace new changes.

\section{2) Changing the objective and content of evaluation}

Over the years, foreign language assessment in higher vocational colleges in China has focused on the examination of students' language knowledge and language application ability. Although the objectives and contents of English testing are adjusted, the practical application of students' English competence is not emphasized. With the attention of the country to foreign language education, the test goal of English for higher vocational students should not only concern knowledge and skills, but also emphasize the ability of language use and critical thinking, so as to realize the educational function of English.

\section{3) Changing the subject of evaluation}

For many years, teachers have been the main body of foreign language teaching and evaluation in higher vocational colleges. Higher vocational colleges can introduce students' mutual evaluation and self-evaluation in English teaching, giving full play to students' main position to increase students' interest in learning English and improve students' language ability. 
4) Changing the evaluation orientation of evaluation quality

At present, in some vocational colleges, "teachers have lost their consciousness of reform, introspection, competition and cooperation, leading to the missing of important factors for teacher's professional development [6]. Only by actively encouraging and supporting English teachers in higher vocational colleges to master all kinds of foreign language teaching skills and strategies, updating the foreign language evaluation concept and using professional spirit can we change this phenomenon. It is not only an eternal topic of teachers' professional development but also one of the important measures to promote the internationalization of higher vocational education to improve the teaching and evaluation literacy of foreign language teachers in higher vocational colleges.

\section{SUMMARY}

The internationalization of higher vocational education is not only the requirement of the times, but also the important content of the connotation construction of each higher vocational college. Only by actively studying the internationalization paths of higher vocational education, absorbing the advantages of international vocational education and sharing the outstanding achievements of international vocational education can we promote the rapid development of higher vocational education in China.

\section{ACKNOWLEDGMENT}

Foundation Project: 2017 Liaoning Province Education Science "13th Five-Year Plan" Education - A Research on Internationalization Development Strategy of Higher Vocational Education in Liaoning Province" (JG17ZXDWB015); 2017 Dalian Vocational and Technical College Scientific Research Project (DZ2017B-09).

\section{REFERENCES}

[1] Shanghai Institute of Educational Sciences, McCormick Research Institute. 2017 Annual Report on the Quality of Higher Vocational Education in China [M]. Beijing: Higher Vocational Education Press, 2017: 49.

[2] Wen Qiufang. The Cultivation of Language Talents under the "Belt and Road"[J].A Study on Language Strategy, 2016(2).

[3] Gu Xiumei, Chen Haizhen. Foreign Language Education Strategies in Higher Vocational Colleges under the Background of "Belt and Road"[J].Chinese Vocational and Technical Education, 2017(1):64-69.

[4] Hou Qiaohong, Zu Jing, Liu Junjuan. New Thoughts on Foreign Language Education in Southern Colleges and Universities Under the Background of Belt and Road[J].Journal of Henan Institute of Engineering,2016 (1).

[5] The National English Proficiency Test Will be introduced in Due Course China Education News, China Education News, China, May 11-30, 2015-30.

[6] Yin Shidong. Eco-oriented Barrier and Operation of Teachers' Professional Development [J]. Teacher Education Research in 2014: 3641. 